\title{
ECLETICA
}

www.scielo.br/eq

www.ecletica.iq.unesp.br

Volume 33, número 3, 2008

\section{A simple spectrophotometric method for the determination of methyldopa using p-chloranil in the presence of Hydrogen Peroxide}

\author{
M. A. Gotardo, L. S. Lima, R. Sequinel, J. L. Rufino, L. Pezza, H. R. Pezza* \\ São Paulo State University - UNESP, Chemistry Institute of Araraquara, P.O. Box 355, 14801-970, \\ Araraquara, SP, Brazil \\ *hrpezza@iq.unesp.br
}

\begin{abstract}
A simple, rapid and sensitive spectrophotometric method has been developed for the determination of methyldopa in pharmaceutical formulations. The method is based on the reaction between tetrachloro- $p$-benzoquinone ( $p$-chloranil) and methyldopa, accelerated by hydrogen peroxide $\left(\mathrm{H}_{2} \mathrm{O}_{2}\right)$, producing a violet-red compound $(\lambda \max =535 \mathrm{~nm})$ at ambient temperature $\left(25.0 \pm 0.2{ }^{0} \mathrm{C}\right)$. Experimental design methodologies were used to optimize the measurement conditions. Beer's law is obeyed in a concentration range from $2.10 \times 10^{-4}$ to $2.48 \times 10^{-3} \mathrm{~mol} \mathrm{~L}^{-1}(\mathrm{r}=0.9997)$. The limit of detection was $7.55 \times 10^{-6} \mathrm{~mol} \mathrm{~L}^{-1}$ and the limit of quantification was $2.52 \times 10^{-5} \mathrm{~mol} \mathrm{~L}^{-1}$. The intraday precision and interday precision were studied for 10 replicate analyses of $1.59 \times 10^{-3} \mathrm{~mol} \mathrm{~L}^{-1}$ methyldopa solution and the respective coefficients of variation were 0.7 and $1.1 \%$. The proposed method was successfully applied to the determination of methyldopa in commercial brands of pharmaceuticals. No interferences were observed from the common excipients in the formulations. The results obtained by the proposed method were favorably compared with those given by the Brazilian Pharmacopoeia procedure at $95 \%$ confidence level.
\end{abstract}

Keywords: spectrophotometry; p-chloranil; hydrogen peroxide; methyldopa; pharmaceutical formulations.

\section{Introduction}

Methyldopa ( $\alpha$-methyl-3, 4-dihydroxyphenylalanine), whose structure is shown in Figure 1 , is a cathecolamine derivative widely used in the control of moderate and severe arterial hypertension. Methyldopa is considered a prodrug since it acts mainly due to its metabolism in the central nervous system to $\alpha$-methylnorepinephrine, a $\alpha_{2}$-adrenergic agonist [1].

Several methods have been proposed to quantify methyldopa in pharmaceutical formulations, including high-performance liquid chro-<smiles>CC(N)(Cc1ccc(O)c(O)c1)C(=O)O</smiles>

Figure 1. Chemical structure of methyldopa.

matography (HPLC) with UV detection [2-5], potentiometry [6], differential pulse polarography [7], titrimetry [8], UV [9,10] and visible spectrophotometry [11-20] and flow injection analysis (FIA) [21-24]. However, many of these methods are timeconsuming and/or require expensive equipment. 
Molecular absorption spectrophotometry is by far the instrumental technique of choice in industrial laboratories, owing mainly to its simplicity, often demanding low-cost equipment and lending itself to easy automation of trace analysis procedures. As already mentioned, a number of UV/visible spectrophotometric methods for methyldopa determination have been reported. The visible spectrophotometric method recommended by the Brazilian Pharmacopeia for methyldopa tablets is based on the reaction with ferrous tartarate at $\mathrm{pH} 8.5$ [11]. Other visible spectrophotometric methods involve the employment of diverse chromogenic reagents such as $\mathrm{N}$-bromosuccinimide and isoniazid [12], barbituric acid [13], sodium nitroprusside in the presence of hydroxylamine hydrochloride [12], periodate in acidic medium [14], diazotized sulphanilamide in the presence of molybdate ions in acidic medium [15], $p$-dimethylaminocinnamaldehyde [16], vanillin in alkaline medium [17], cerium (IV) nitrate [18], ferric chloride in acidic medium [19], iron(III) in the presence of 1,10-phenanthroline and 2,2'-bipyridyl [20]. The methods by FIA with spectrophotometric detection involve the use of $p$-toluidine and sodium periodate [21], metaperiodate [22], $p$-aminophenol in alkaline medium [23] and ammonium molybdate [24] as chromogenic reagents. Nevertheless, most of the aforementioned methods present some limitations and drawbacks such as low selectivity [9], long waiting time for the color development $[17,18]$, or heating step $[9,13,18,22]$. Still, there is in the literature a spectrophotometric method for the determination of methyldopa in pharmaceutical formulations using $p$-chloranil [10]. However, this method that is based on UV absorption $(358 \mathrm{~nm})$ shows problems related to low selectivity and requires a tedious heating step (30 minutes).

According to above considerations, the need for a simple, fast, low-cost, and selective method for determination of methyldopa seems clear. The method described in this paper is based on the reaction between methyldopa and tetrachloro-p-benzoquinone ( $p$-chloranil), accelerated by hydrogen peroxide, yielding a violet-red compound $(\lambda \max =535$ $\mathrm{nm})$ at ambient temperature $\left(25.0 \pm 0.2^{\circ} \mathrm{C}\right)$. This work proposes the employment of $\mathrm{H}_{2} \mathrm{O}_{2}$ as a good strategy to accelerate the previously mentioned reaction. In this case, the heating step is not required. In addition, the reaction conditions were studied by experimental design approaches in order to optimize the analytical response.
The analytical results obtained by applying the proposed method are trustworthy when compared with those given by Brazilian Pharmacopeia standard procedure.

\section{Experimental}

\section{Apparatus}

The absorbance measurements for the proposed method and for the standard method were performed using a portable UV/VIS spectrophotometer (USB 4000 model - Ocean Optics); with wavelength range work $200-850 \mathrm{~nm}$ and equipped with a cell of $10 \mathrm{~mm}$ path length. Software OOI Base 32 (Ocean Optics) was used for acquisition and storage of the spectral data.

\section{Materials}

Pharmaceutical formulations (tablets) of four commercial brands were analyzed. These tablets were purchased from local drugstores and all were tested prior to the listed expiration date. All studied pharmaceuticals were package labeled to contain $250 \mathrm{mg}$ of methyldopa per tablet.

The excipients used in the interference study were of pharmaceutical grade.

\section{Reagents and solutions}

All reagents and solvents employed were of analytical grade. Acetone, methanol (Mallinckrodt, Xalostoc, Mexico) were used. p-Choranil (Sigma, St Louis, E.U.A.) was used to prepare a $4.07 \times 10^{-2}$ $\mathrm{mol} \mathrm{L}^{-1}(1.0 \%, \mathrm{w} / \mathrm{v})$ solution in acetone. A $4.55 \mathrm{~mol}$ $\mathrm{L}^{-1}$ hydrogen peroxide solution was prepared by appropriate dilution of $\mathrm{H}_{2} \mathrm{O}_{2} 30 \%$ (w/w) (Merck, Darmstadt, Germany) in methanol and standardized by permanganometric titration, according to the procedure described in the literature [25]. A stock standard solution of methyldopa (Henrifarma - São Paulo, Brazil, purity grade $>99.8 \%$ ) in methanol was prepared at $1.68 \times 10^{-2} \mathrm{~mol} \mathrm{~L}^{-1}$ and working solutions were prepared by convenient dilutions with methanol. All solutions were daily prepared.

\section{Preparation of the analytical curve}

Aliquots from the methyldopa stock solution $\left(1.68 \times 10^{-2} \mathrm{~mol} \mathrm{~L}^{-1}\right)$ were transferred into 5.00 $\mathrm{mL}$ volumetric flasks in order to obtain an analytical curve in the concentration range from $2.10 \times 10^{-}$ 4 to $2.48 \times 10^{-3} \mathrm{~mol} \mathrm{~L}^{-1}$. After that, $770 \mu \mathrm{L}$ of $p$ chloranil solution $\left(4.07 \times 10^{-2} \mathrm{~mol} \mathrm{~L}^{-1}\right)$ and $85 \mu \mathrm{L}$ 
of $\mathrm{H}_{2} \mathrm{O}_{2}$ (4.55 mol L-1) were added. The final volume was completed to $5.00 \mathrm{~mL}$ with methanol. The absorbance measurements were carried out at 535 nm against reagents blank. The analytical curve was obtained by plotting absorbance values versus methyldopa concentration in $\mathrm{mol} \mathrm{L}^{-1}$. (tablets)

Analysis of pharmaceutical formulations

Twenty tablets of each commercial pharmaceutical brand to be studied were weighed and finely powdered. A portion of this powder, equivalent to c.a. $100 \mathrm{mg}$ of methyldopa, was accurately weighed. The sample was shaking with methanol in a magnetic mixer for $10 \mathrm{~min}$ and transferred into a $25 \mathrm{~mL}$ volumetric flask and the volume completed with methanol. The solution was filtered in Whatman 41 filter paper and an aliquot from this filtered solution was analyzed according to the procedure described in the preparation of the analytical curve.

\section{Results and discussion}

$p$-Chloranil has been used as chromogenic reagent for the determination of several drugs, such as fluoxetine and sertraline [26,27], paroxetine[27], salbutamol [28], nortriptyline [29], tranquillizers and antidepressants [30], trimetazidine dihydrochloride [31], b-adrenergic blockers [32], dicyclomine hydrochloride [33], omeprazole [34], isoprenaline and methyldopa [10]. These methods are based on the interaction between electrons donors (drugs) and $p$-chloranil, which acts as an electron acceptor producing intensely colored charge transfer complexes (Scheme 1) [35].

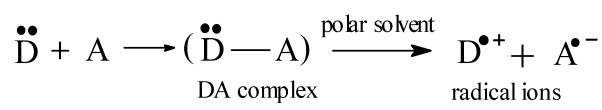

Scheme 1. Chemical structure of methyldopa.

$p$-Chloranil has been also used to detect methyldopa in pharmaceutical formulations on thin-layer [36]. As aforementioned, a spectrophotometric method for the determination of methyldopa using $p$-chloranil as chromogenic reagent [10] shows problems related with the low selectivity, requires a tedious heating step (30 minutes) and involve various manipulation steps.
In order to develop a simple procedure, the proposed method used the reaction between methyldopa and $p$-chloranil, which was markedly accelerated in the presence of $\mathrm{H}_{2} \mathrm{O}_{2}$. This reaction produced a colored compound at ambient temperature $\left(25.0 \pm 0.2^{\circ} \mathrm{C}\right)$ and the absorbance measurements were carried out at $535 \mathrm{~nm}$.

Figure 2 shows the absorption spectrum of the product of the reaction between methyldopa and $p$-chloranil in the presence of $\mathrm{H}_{2} \mathrm{O}_{2}$. As it can be noted (Figure 2), the spectrum exhibits large bands, which are characteristic of charge transfer complexes [35]. It should be also observed in Figure 2 that the spectrum exhibits a maximum absorption band at $535 \mathrm{~nm}$ and another at $535 \mathrm{~nm}$.

The study of the optical stability reveals that the colored complex is stable at least $60 \mathrm{~min}$ at $435 \mathrm{~nm}$. It is important to emphasizes that in the absence of $\mathrm{H}_{2} \mathrm{O}_{2}$ the reaction was extremely slow and the product was not stable.

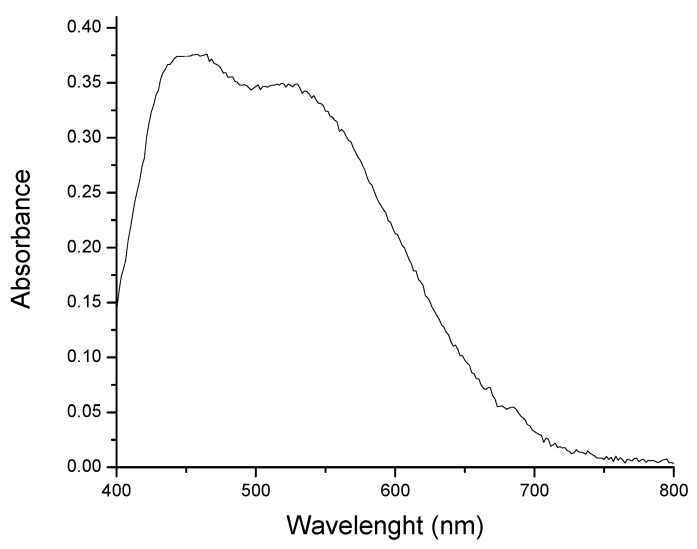

Figure 2. Absorption spectrum of the product of the reaction between methyldopa and p-chloranil in the presence of $\mathrm{H}_{2} \mathrm{O}_{2}$. The analytical wavelength was $535 \mathrm{~nm}$. Methyldopa solution was at $1.07 \times 10^{-3} \mathrm{~mol}$ $\mathrm{L}^{-1}$, optical path $=1 \mathrm{~cm}$.

To the best of our knowledge, there is a single spectrophotometric method for the determination of saccharin using $p$-cloranil described in the literature that also used $\mathrm{H}_{2} \mathrm{O}_{2}$ as accelerator agent [37]. So, our results corroborate with those already described for analysis of saccharin, suggesting that reactions involving $p$-chloranil and electrons donors could be accelerated by using of $\mathrm{H}_{2} \mathrm{O}_{2}$. 


\section{Experimental design}

In order to investigate the best conditions for the reaction between $p$-chloranil and methyldopa in the presence of $\mathrm{H}_{2} \mathrm{O}_{2}$ an experimental design using central composite design was employed.

Central composite design allowed studying simultaneously the two factors that could have an important effect on the reaction. The factors of interest were $p$-chloranil and $\mathrm{H}_{2} \mathrm{O}_{2}$ concentration. To study these factors, aliquots were taken of the $4.07 \times 10^{-2} \mathrm{~mol} \mathrm{~L}^{-1} p$-chloranil solution and $4.55 \mathrm{~mol} \mathrm{~L}^{-1} \mathrm{H}_{2} \mathrm{O}_{2}$ solution, respectively. Table 1 shows the equivalent matrix of the central composite design as well as the absorbance data. The experiment corresponding to the central point was carried out in four replicates. All experiments were carried out with solution of methyldopa set at $1.59 \times 10^{-3} \mathrm{~mol} \mathrm{~L}^{-1}$.

Table 1. Matrix and results from of the central composite design.

\begin{tabular}{lccc}
\hline \multirow{2}{*}{ Experiments } & \multicolumn{2}{c}{ Factor } & \multirow{2}{*}{ Response } \\
\cline { 2 - 3 } & $\begin{array}{c}\text { p-Chloranil } \\
\text { volume }(\mathrm{mL})^{\mathrm{a}}\end{array}$ & $\begin{array}{c}\mathrm{H}_{2} \mathrm{O}_{2} \\
\text { Volume }(\mathrm{mL})^{\mathrm{b}}\end{array}$ \\
\hline \multicolumn{2}{c}{$\mathrm{A}(535 \mathrm{~nm})$} \\
\hline 1 & 600 & 40 & 0.4397 \\
2 & 1100 & 40 & 0.5454 \\
3 & 600 & 90 & 0.5921 \\
4 & 1100 & 90 & 0.5813 \\
5 & 850 & 65 & 0.5978 \\
6 & 850 & 65 & 0.6151 \\
7 & 850 & 65 & 0.6094 \\
8 & 850 & 65 & 0.6165 \\
9 & 500 & 65 & 0.5946 \\
10 & 1200 & 65 & 0.5973 \\
11 & 850 & 30 & 0.5758 \\
12 & 850 & 100 & 0.6055 \\
\hline
\end{tabular}

a $p$-Chloranil solution at $4.07 \times 10^{-2} \mathrm{~mol} \mathrm{~L}^{-1}$.

b $\mathrm{H}_{2} \mathrm{O}_{2}$ solution at $4.55 \mathrm{~mol} \mathrm{~L}^{-1}$.

The absorbance values obtained experimentally from central composite design were represented by a three-dimensional graph that is known as response surface (Figure 3 ). The experimental data were fitted to the response surface in order to obtain the optimum reaction conditions.

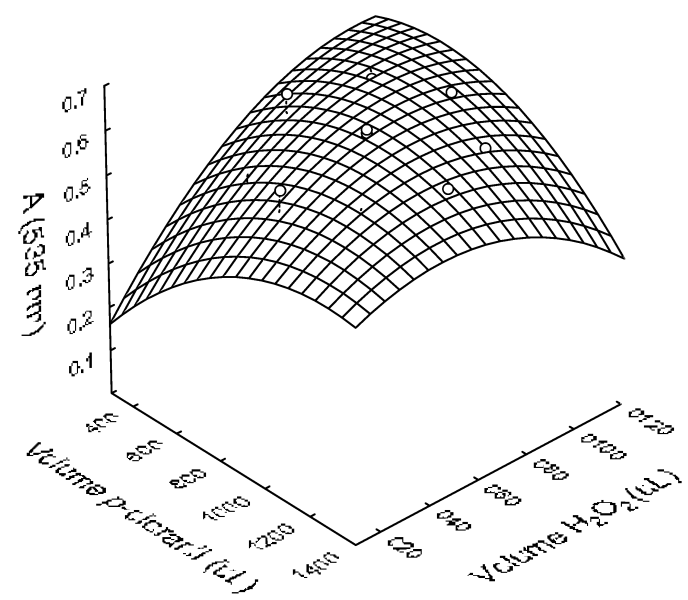

Figure 3. Response surface of quadratic model for absorbance values as a function of $p$-chloranil volume and $\mathrm{H}_{2} \mathrm{O}_{2}$ volume.

The quadratic regression model is given by:

$Z=0.177376+0.000965 x+0.009891 y-0.000037 y^{2}$

where, $\mathrm{Z}$ is the response factor corresponding to the absorbance value. The factors $\mathrm{x}$ and $\mathrm{y}$ are the $p$ chloranil volume and $\mathrm{H}_{2} \mathrm{O}_{2}$ volume, respectively. The coefficient value of $\mathrm{x}^{2}$ factor as well as the coefficients of the interactions of the factors were very small and for this reason they were not shown.

It can be observed by the surface shape (Figure 3) that the optimal region was found and that the maximum responses were achieved with $770 \mu \mathrm{L}$ of $p$-chloranil solution and $85 \mu \mathrm{L}$ of $\mathrm{H}_{2} \mathrm{O}_{2}$.

\section{Analytical characteristics}

The proposed analytical method was validated by evaluating linear dynamic range, precision, limit of detection (LOD), and limit of quantification(LOQ). Under the described experimental conditions Beer's law is obeyed in the concentration range from $2.10 \times 10^{-4}$ to $2.48 \times 10^{-3} \mathrm{~mol}$ $\mathrm{L}^{-1}\left(50-590 \mathrm{mg} \mathrm{mL}^{-1}\right)$, with a correlation coefficient of 0.9997 . The absorbance values for this concentration range were adjusted by the equation: $\mathrm{A}=-0.0401+364.315 \times \mathrm{C}$, where $\mathrm{C}$ is the concentration of methyldopa in $\mathrm{mol} \mathrm{L}^{-1}$ and the angular coefficient value corresponds to the molar absorptivity $(\varepsilon)$, that is $3.64 \times 10^{2} \mathrm{~L} \mathrm{~mol}^{-1} \mathrm{~cm}^{-1}$.

Assay of precision was defined by determining intraday and interday precision, 
expressed as relative standard deviation (RSD). The interday variation was evaluated over 3 days. The intraday and interday precision were studied for 10 replicate analyses of $1.59 \times 10^{-3} \mathrm{~mol} \mathrm{~L}^{-1}$ methyldopa solution. The coefficients of variation were 0.7 and $1.1 \%$ respectively, indicating that the proposed method has high repeatability.

In order to investigate the presence of matrix effects on the proposed method, a recovery study was carried out. In this study, $2.52 \times 10^{-4}$; $5.04 \times 10^{-4} ; 7.55 \times 10^{-4}$ and $1.00 \times 10^{-3} \mathrm{~mol} \mathrm{~L}^{-1}$ of methyldopa reference solutions were added in three representative pharmaceuticals (samples A,B and C). Recovery mean values for all samples $(n=3)$ ranged from $97.8-102.7 \%$ indicating the absence of significant matrix effects on the measurements. The LOD (3.SD blank/ slope of analytical

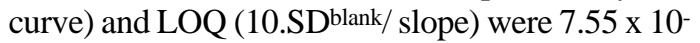
6 and $2.52 \times 10^{-5} \mathrm{~mol} \mathrm{~L}^{-1}$, respectively [38].

\section{Study of interferences}

Since the aim of this study was to determine methyldopa in pharmaceuticals, the effects of the most commonly used excipients were carefully examined. The excipients studied were starch, talc, magnesium stearate, tartaric acid, polyethyleneglycol, polypropyleneglycol, cellulose, ethylcellulose, hydroxypropylmethylcellulose, lactose, silicon dioxide and sodic croscarmelose. For this study, solutions containing methyldopa and each of the excipients taken separately in concentrations equal or 10 times greater than that of methyldopa were shaking with methanol in a magnetic mixer for 10 minute, diluted, filtered when necessary, and analyzed under the same conditions described in the preparation of analytical curve.

The effect of each excipient was considered interference when the absorbance signal showed an error equal or more than $3 \%$ in the determination of the drug. The percentage of methyldopa found in these solutions ranged of 97.4 to $103.1 \%$, with variation coefficients values less than $3 \%$ for three replicates, indicating that no interferences were observed under the studied conditions.

\section{Analytical application}

The applicability of the proposed method for determination of methyldopa in commercial dosage were statistically [39] compared with those obtained by the Brazilian Pharmacopoeia procedure [11] and are summarized in Table 2. In all cases, the calculated $\mathrm{F}$ and $\mathrm{t}$ values did not exceed the theoretical values, indicating that there is no significant difference between the performance of the two methods as regard accuracy (t-test) and precision (F-test).

Table 2. Determination of methyldopa in pharmaceutical formulations.

\begin{tabular}{|c|c|c|c|c|}
\hline \multirow[t]{2}{*}{ Samplesa } & \multicolumn{2}{|c|}{$\begin{array}{l}\text { Proposed } \\
\text { method }\end{array}$} & \multicolumn{2}{|c|}{$\begin{array}{l}\text { Pharmacopeial } \\
\text { method }^{11}\end{array}$} \\
\hline & $\begin{array}{c}\text { Found valueb } \\
\text { (mg/tablet) }\end{array}$ & $\begin{array}{l}t \text { value } \\
(2.78)^{\mathrm{c}}\end{array}$ & $\begin{array}{l}\text { F value } \\
(19.00)^{c}\end{array}$ & $\begin{array}{c}\text { Found value } \\
\text { (mg/tablet) }\end{array}$ \\
\hline A & $250.3 \pm 2.1$ & 0.67 & 2.97 & $249.0 \pm 1.8$ \\
\hline B & $248.1 \pm 1.6$ & 1.92 & 4.00 & $249.9 \pm 1.2$ \\
\hline $\mathrm{C}$ & $248.6 \pm 2.3$ & 0.46 & 1.83 & $248.4 \pm 1.7$ \\
\hline D & $253.5 \pm 3.1$ & 0.82 & 4.90 & $254.2 \pm 1.4$ \\
\hline
\end{tabular}

a Package labeled to contain $250 \mathrm{mg}$ methyldopa per tablet.

${ }^{\mathrm{b}}$ Average \pm standard deviation (SD) of three determinations $(\mathrm{n}=3)$.

${ }^{c}$ Theoretical values of $\mathrm{t}$ and $\mathrm{F}$ at $95 \%$ confidence level

\section{Conclusions}

The proposed spectrophotometric method, which is simple, rapid and inexpensive provide gain of sensitivity without the need of additional step as extraction or heating. The method does not involve stringent reaction conditions and gives precise and accurate results. Its usefulness for methyldopa determination in pharmaceutical formulations was demonstrated, suggesting its use as an attractive alternative to many other previously reported methods for analysis of methyldopa.

\section{Acknowledgements}

We would like to thank Capes, $\mathrm{CNPq}$ and FAPESP foundations (Brazil) for financial support.

Received May 142008

Accepted July 182008 
M. A. Gotardo, L. S. Lima, R. Sequinel, J. L. Rufino, L. Pezza, H. R. Pezza. Um método espectrofotométrico simples para a determinação de metildopa usando $p$-cloranil na presença de peróxido de hidrogênio.

Resumo: Este trabalho descreve um método espectrofotométrico simples, rápido e sensível para a determinação de metildopa em formulações farmacêuticas. O método é baseado na reação entre tetracloro-pbenzoquinona (p-cloranil) e metildopa, a qual é acelerada por peróxido de hidrogênio $\left(\mathrm{H}_{2} \mathrm{O}_{2}\right)$, produzindo um composto vermelho-violeta $(\lambda \max =535 \mathrm{~nm})$ à temperatura ambiente $\left(25,0 \pm 0,2{ }^{\circ} \mathrm{C}\right)$. As melhores condições para a reação foram obtidas por planejamento experimental. A lei de Beer é obedecida em um intervalo de concentração de $2,10 \times 10^{-4}$ to $2,48 \times 10^{-3} \mathrm{~mol} \mathrm{~L}^{-1}(\mathrm{r}=0,9997)$. O limite de detecção determinado foi de $7,55 \times 10^{-6} \mathrm{~mol} \mathrm{~L}^{-1}$ e o limite de quantificação foi de $2,52 \times 10^{-5} \mathrm{~mol} \mathrm{~L}^{-1}$. A precisão intradia e interdia do método proposto foram determinadas pela análise em decuplicata $(n=10)$ de uma solução de metildopa $1,59 \times 10^{-3} \mathrm{~mol} \mathrm{~L}^{-1}$ e apresentaram coeficientes de variação de 0,7 e $1,1 \%$, respectivamente. $\mathrm{O}$ método proposto foi aplicado com sucesso na determinação de metildopa em diferentes marcas de medicamentos. Os resultados obtidos pelo método proposto estiveram em boa concordância com aqueles obtidos pelo método da Farmacopéia Brasileira em um nível de confiança de $95 \%$.

Palavras-chave: espectrofotometria; p-cloranil; peróxido de hidrogênio; metildopa; formulações farmacêuticas.

\section{References}

[1] B.B. Hoffman, in: J.G. Hardman, L.E. Limbird, A Goodman-Gilman (Eds.), As Bases Farmacológicas da Terapêutica, McGraw-Hill, Rio de Janeiro, 2003, pp. 163. [2] R.M.V. Camanas, J.M.S. Mallols, J.R.T. Lapasio, G. Ramis-Ramos, Analyst 120 (2005) 1767.

[3] M. Zecevic, L. Zivanovic, S.K. Agatonovic, D. Minic, J. Pharm. Biomed. Anal. 24 (2001) 1019.

[4] S. Ting, J. Assoc. Off. Anal. Chem. 66 (1983) 1436.

[5] S. Ting, J. Assoc. Off. Anal. Chem. 67 (1984) 1118.

[6] S.S. Badawy, Y.M. Issa, A.S. Tag-Eldin, Electroanalysis 8 (1996) 1060.

[7] J. Ballantine, A.D. Woolfson, Int. J. Pharmaceutics 3 (1979) 239.

[8] V.N. Pathak, M.S.R. Shukla, I.C. Shukla, Analyst 107 (1982) 1086.

[9] A.A.M. Wahbi, H. Abdine, M. Korany, M.H. Abdel-Hay, J. Assoc. Off. Anal. Chem. 61 (1978) 1113.

[10] M.A. Korany, A.M. Wahbi, Analyst 104 (1979) 146.

[11] Farmacopéia Brasileira, fourth ed., Atheneu, São Paulo, 1996, pp. 47.1.

[12] P. Nagaraja, K.C.S. Murthy, K.S. Rangappa, N.M.M Gowda, Talanta 46 (1998) 39.

[13] T. Aman, I.U. Khan, N. Aslam, I. Ahmad, Anal. Lett. 31 (1998) 1007.

[14] A. Afkhami, H.A. Khatami, J. Anal. Chem. 58 (2003) 135.

[15] P. Nagaraja, R.A. Vasantha, K.R. Sunitha, J. Pharm Biomed. Anal. 25 (2001) 417.

[16] M.I. Walash, A. Abou-Ouf, F.B. Salem, J. Assoc. Off. Anal. Chem. 68 (1985) 91.

[17] F.B. Salem, Anal. Lett. 18 (1985) 1063.

[18] M.I.H. Helaleh, N. Rahman, A.N. Nafisur, S.M. Eyad, Anal. Sci. 13 (1997) 1007.

[19] L. Zivanovic, M. Vasiljevic, S. Agatonovic, D. Radulovic, Boll. Chim. Farm. 130 (1991) 162.
[20] B.S. Nagaralli, J. Seetharamappa, M.B. Melwanki, K.C. Ramesh, J. Keshavayya, J. AOAC Int. 85 (2002) 1288.

[21] L.K. Abdulrahman, A.M. Al-Abachi, M.H. Al-Qaissy, Anal. Chim. Acta 535 (2005) 331.

[22] J.J.B. Nevado, J.M.L. Gallego, P.B. Laguna, Fresenius J. Anal. Chem. 353 (1995) 221.

[23] M. Tubino, A. Rodrigues Jr., M.M.D.C. Vila, J. Flow Injection Anal. 21 (2004) 132

[24] P.R.S. Ribeiro, J.A. Gomes Neto, L. Pezza, H.R. Pezza, Talanta 67 (2005) 240.

[25] O.A. Ohlweiler, Química Analítica Quantitativa, Livros Técnicos e Científicos, Rio de Janeiro, 1982.

[26] L.I. Bebawy, N.M. El-Kousy, J.K. Suddik, M. Shokry, J.

Pharm. Biomed. Anal. 21 (1999) 133.

[27] I.A. Darwish, J. AOAC Int. 88 (2005) 38

[28] R.S. Bakry, O.A. Razak, A.F.M. El-Walily, S.F. Belal, J. Pharm. Biomed. Anal. 14 (1996) 357.

[29] F.M.A. Attia, Farmaco 55 (2000) 659.

[30] E.A. Ibrahim, A.S. Issa, M.A.A. Salam, M.S. Mahrous, Talanta 30 (1983) 531.

[31] I.A. Darwish, Anal. Chim. Acta 551 (2005) 222.

[32] H. Salem, J. Pharm. Biomed. Anal. 29 (2002) 527.

[33] L.I. Bebawy, Y.M. Issa, K.M.A. Moneim, J. AOAC Int. 86 (2003) 1.

[34] N.M. El-Kousy, L.I. Bebawy, J. AOAC Int. 82 (1999) 599.

[35] R. Foster, Organic Charge-Transfer Complexes, Academic Press, London, 1968.

[36] M.U. Adikwu, U. Ajali, G.B. Okide, U.E. Odoh, Boll. Chim. Farm. 141 (2002) 315.

[37] P.L. Weinert, H.R. Pezza, J.E. Oliveira, L. Pezza, J. Agric. Food Chem. 52 (2004) 7788.

[38] G.L. Long, J.D. Winefordner, Anal. Chem. 55 (1983) $712 \mathrm{~A}$.

[39] J. C. Miller, J. N. Miller, Statistics for Analytical Chemistry, second ed., Ellis Horwood Limited, London, 1992. 